\title{
Prevalência e perfil de resistência aos Antimicrobianos dos Sorovares de Salmonella sp isoladas de carcaças de frango e peru na Região Sul do Brasil no período de 2004 a 2006*
}

\author{
ANDRÉ LUIZ BAGOLIN PALMEIRA
}

Vladimir Pinheiro do Nascimento (Orientador - UFRGS)

Banca: Elci Lotar Dickel(UPF), Hamilton Luiz de Souza Moraes(UFRGS), Maristela Lovato Flôres(UFSM)

\begin{abstract}
A Salmonella sp. permanece com um dos mais importantes patógenos transmissores de enfermidades veiculadas através dos alimentos em todo mundo. A carne de aves está entre as principais causadoras das toxinfecções alimentares quando contaminadas pelo gênero Salmonella. Neste estudo foram isolados 280 sorovares de Salmonella das carcaças de frango e peru através do Programa de Redução de Patógenos (PRP-MAPA) na região sul do país. Foram 25 os sorovares de Salmonella sp isolados das carcaças de aves. Destes apenas 14 em perus e 23 nos frangos. A S. Tennessee e Salmonella enterica subespecie enterica (O: 4,5), foram isoladas somente em carcaças de perus e a S. Hadar foi a mais prevalente (18,6\%). A maior prevalência ocorreu para a Salmonella Enteritidis (55,7\%). Nas carcaças de frango, a S. Enteritidis alcançou 63,3\% dos isolados, porém nas carcaças de peru este sorovar não passou dos 14,0\%. Entre os estados do sul (PR, SC e RS), não houve diferenças nos isolados de S.Enteritidis. Nos testes de difusão em placas, foram desafiadas 178 cepas frente a 24 antimicrobianos. Todas as cepas de Salmonella sp foram resistentes a bacitracina e a penicilina e 78,2\% apresentaram resistência a pelo menos um antimicrobiano quando excluídas as drogas anteriormente citadas, sendo que todas as amostras foram sensíveis a amoxicilina + ácido clavulânico, polimixina B, ciprofloxacina e norfloxacina. A maior taxa de resistência das amostras foi observada frente ao ácido nalidíxico de $52,2 \%$, seguido da nitrofurantoína $(28,8 \%)$, neomicina $(14,6)$, tetraciclina $(12,4 \%)$ e canamicina $(10,1 \%)$. Nas amostras isoladas de perus estes índices foram maiores para o ácido nalidíxico (62,8\%), tetraciclina (34,9\%) e neomicina (30,2\%), havendo diferenças significativas para os dois últimos quando comparados aos isolados de frango. Embora o índice de resistência a enrofloxacina de 2,2\% no segmento aves seja baixo, chama atenção que, por tratar-se de um antimicrobiano quimicamente modificado a taxa de resistência nas amostras de perus tenha sido de 9,3\%.O sorovar S. Enteritidis apresentou a maior taxa de resistência ao ácido nalidíxico $(72,0 \%)$ e menor para tetraciclina (1,1\%). Por outro lado, foi comprovada a presença de cepas multiresistentes em 46,1\% dos isolados das carcaças de aves, principalmente nas amostras de perus nos sorovares S. Hadar e S. Saintpaul, que foram resistentes no mínimo a quatro e no máximo onze antimicrobianos. Este estudo demonstrou qual a prevalência e o perfil de resistência aos antimicrobianos dos sorovares de Salmonella sp isoladas das carcaças de aves na região Sul do Brasil e devido a sua importância em saúde animal e saúde pública, pode sugerir a criação de um Programa Nacional de Monitoramento da Resistência Bacteriana aos Antimicrobianos.
\end{abstract}

Descritores: antimicrobianos, frango, multiresistência, peru, Salmonella, resistência.

Apresentada: 28 fevereiro 2007

*Dissertação de Mestrado n. 467 (Especialidade: Sanidade Avícola). 55f. Programa de Pós-graduação em Ciências Veterinárias [www.ufrgs.br/ ppgcv], Faculdade de Veterinária, Universidade Federal do Rio Grande do Sul (UFRGS), Porto Alegre, RS/Brasil. CORRESPONDÊNCIA: A.L.B. Palmeira [andrepalmeira@agricultura.gov.br]. 


\title{
Prevalence and Antimicrobial resistance profile of Salmonella sp. isolated from broiler chicken and turkey carcasses in southern Brazil during the period (2004 to 2006)**
}

\author{
ANDRÉ LUIZ BAGOLIN PALMEIRA \\ Vladimir Pinheiro do Nascimento (Adviser - UFRGS)
}

Committee: Elci Lotar Dickel(UPF), Hamilton Luiz de Souza Moraes(UFRGS), Maristela Lovato Flôres(UFSM)

\begin{abstract}
Salmonella sp. remains as one of the most important foodborne pathogens worldwide. Poultry meat is among the most frequently involved foods regarding human food poisoning cases. In this study, two hundred and eighty Salmonella isolates were detected from broiler and turkey carcasses submitted to the Brazilian Ministry of Agriculture, Livestock and Supply (MAPA)'s Pathogens Reduction Program (PRP-MAPA) in Southern Brazil. Twenty five Salmonella serovars were isolated in the poultry carcasses, being 14 in turkey and 23 in broilers. The most prevalent serovar was Salmonella Enteritidis $(57,7 \%)$. In broiler carcasses, S. Enteritidis reached a 63,3\% prevalence, while in turkeys carcasses this serovar presented a comparatively lower index (14,0\%). Among the Brazilian Southern States (PR, SC and RS) there were no significative differences in the percentage of isolated S. Enteritidis. S. Tennessee and Salmonella enterica subspecies enterica $(\mathrm{O}: 4,5)$ were isolated in turkeys, but not in broiler carcasses. S. Hadar was most prevailing in turkeys $(18,6 \%)$. Regarding the diffusion test applied to 178 isolates, they were challenged against 24 antimicrobials. As expected, all isolates were resistant to bacitracin and penicillin, while $78,2 \%$ presented resistance to at least one antimicrobial drug when the ones above were excluded. All samples were sensitive to amoxicillin + clavulanic acid, polymixin B, cyprofloxacin and norfloxacin. The highest resistance rate was observed against nalidixic acid (52,2\%), followed by nitrofurantoin $(28,8 \%)$, neomycin $(14,6 \%)$, tetracycline $(12,4 \%)$ and canamycin $(10,1 \%)$. In turkeys the rates were higher to nalidixic acid $(62,8 \%)$, tetracycline $(34,9 \%)$ and neomycin $(30,2 \%)$ showing significant differences for the latter two when compared to the ones isolated in broilers. S. Enteriditis isolates showed a higher resistance to nalidixic acid $(72,0 \%)$ and lower to tetracycline $(1,1 \%)$. Presence of multiresistant isolates was proven in $46,1 \%$ of the isolated poultry carcasses, mainly in the turkey samples related to the presence of S. Hadar and S. Saintpaul serovars, which were resistant to at least four to a maximum of eleven antimicrobials. This study was able to demonstrate the prevalence and the antimicrobial resistance profile of Salmonella serovars isolated from poultry carcasses in Southern Brazil. These findings reinforce the need for the creation of a National Antimicrobial Resistance Monitoring Programme in Brazil, which will be able to contribute to an overdue controlled use of these drugs in food producing animals.
\end{abstract}

Key words: Salmonella, turkeys, broilers, antimicrobial resistance, multiresistance.

Presented: 28 February 2007

\footnotetext{
**Master's Thesis \# 467 (Field: Avian Pathology). 55p. Graduate Program in Veterinary Sciences [www.ufrgs.br/ppgcv], Faculdade de Veterinária, Universidade Federal do Rio Grande do Sul (UFRGS), Porto Alegre, RS/Brazil. CORRESPONDENCE: A.L.B. Palmeira [andrepalmeira@agricultura.gov.br].
} 